研 究

\title{
$\mathrm{Bi}$ 系銅酸化物超伝導体におけるカーボンナノチューブ混合による相構成の変化と 電気伝導性への影響
}

\author{
岡野 佑輔, 櫻井 宏樹, 中村 寿樹, 大橋憲太郎 \\ 金沢工業大学, = 921-8501 石川県石川郡野々市町扇が丘 7-1.
}

\section{The Change of Assembly and the Effect of Carbon-Nano-Tube Mixing on the Electric Conductivity in $\mathrm{Bi}_{2} \mathrm{Sr}_{2} \mathrm{Ca}_{2} \mathrm{Cu}_{3} \mathrm{O}_{y}$ Superconductors}

\author{
Yusuke Okano, Hiroki Sakurai, Toshiki Nakamura and Kentaro Ohhashi \\ Kanazawa Institute of Technology, 7-1 Ohgigaoka Nonoichi-machi, Ishikawa 921-8501, Japan.
}

Received September 19, 2006

\begin{abstract}
SYNOPSIS
In order to improve pinning properties of bulk $\mathrm{Bi}_{2} \mathrm{Sr}_{2} \mathrm{Ca}_{2} \mathrm{Cu}_{2} \mathrm{O}_{\mathrm{y}}$ (Bi2223) materials, samples of both pure $\mathrm{Bi}-2223$ and $\mathrm{Bi} 2223$ with carbon nanotubes (CNT) embedded have been prepared by solid state reaction method. The parent samples mixed with $0 \sim 5 \mathrm{wt} \%$ of CNT were heated at $800^{\circ} \mathrm{C}$ for $24 \mathrm{~h}$ in air or $\mathrm{N}_{2}$ atomosphere. We could not find any great improvement of critical current density $\mathrm{J}_{\mathrm{c}}$ due to reduction property of CNT.
\end{abstract}

KEY WORDS

Bi-2223 high-Tc superconductor, Carbon nanotube, critical current density

\section{1 緒 言}

超伝導体には, 弱い磁場で超伝導体が壊れてしまう第一種 超伝導体と磁場とうまく共存できる第二種超伝導体が存在す る.第一種超伝導体は臨界磁場Hcの值が小さいため, 超伝導 磁石のコイルとしての利用には不適切である. 第2 種超伝導 体は, 磁場が小さいところではマイスナ一効果を示すがある 磁場以上になると磁場の侵入を許し, 磁化を減少させる. 磁 場が侵入した部分の超伝導は壞れるが, そのまわりは壊れず に超伝導を維持する. 第二種超伝導体は臨界磁場が比較的大 きく電気的性質は不純物の量や加工方法によって大きく変化 させることができ, 超伝導磁石, 超伝導送電, 高周波材料な ぞに幅広く応用できる. 本研究で使用する酸化物超伝導体は 第二種に分類される.

$\mathrm{Bi}$ 系銅酸化物超伝導体の中で代表的なものは, 組成式を $\mathrm{Bi}_{2} \mathrm{Sr}_{2} \mathrm{Ca}_{\mathrm{n}-1} \mathrm{Cu}_{\mathrm{n}} \mathrm{O}_{\mathrm{y}}(\mathrm{n}=1,2,3)$ で表し, それぞれ 2201 相 $(\mathrm{n}=1)$, 2212 相 $(\mathrm{n}=2), 2223$ 相 $(\mathrm{n}=3)$ と呼ばれる. $\mathrm{Bi}$ 系銅酸化物超伝 導体の電気伝導は $\mathrm{CuO}_{2}$ 面が担っており, $\mathrm{BiO}$ 面間にある $\mathrm{CuO}_{2}$ 面の枚数によって臨界温度 $\mathrm{Tc}$ が異なる. $\mathrm{CuO}_{2}$ 面が1枚の 2201 相は極低温相 $\mathrm{Tc}=4 \sim 20 \mathrm{~K}, 2$ 枚の 2212 相は低温相 $\mathrm{Tc}=80$ 〜 $90 \mathrm{~K}, 3$ 枚の 2223 相は高温相 $\mathrm{Tc}=100 \sim 110 \mathrm{~K}$ と呼ぶ. 初期 の研究では, 含まれる $\mathrm{CuO}_{2}$ 面の面数が増えることにより臨界 温度Tcの上昇が期待されたが, それには限度があることがわ
かり,現在までの $\mathrm{CuO}_{2}$ 面を5枚持つ物質が合成されているが, $\mathrm{CuO}_{2}$ 面が 3 枚のもので臨界温度 $\mathrm{Tc}$ がピークに達する ${ }^{1)}$.

$\mathrm{Bi}$ 系銅酸化物超伝導体は変形ぺロブスカイト構造を持つ正 方晶系の層状物質であり, 重なり合った $\mathrm{Bi}-\mathrm{O}$ 面における層の 重なりに不整が存在し, $\mathrm{c}$ 軸に沿って繰り返し周期は長く なっていく. 格子定数 $\mathrm{a}=\mathrm{b} \fallingdotseq 0.54 \mathrm{~nm}, \mathrm{c} \fallingdotseq 2.4 \mathrm{~nm}$ (2201 相), $\mathrm{c} \fallingdotseq 3.1 \mathrm{~nm}$ (2212 相), $\mathrm{c} \fallingdotseq 3.7 \mathrm{~nm}$ (2223 相) である.

超伝導体にはゼロ抵抗, ジョセフソン効果, マイスナ一効 果の 3 つの特徵がある. 第 2 種超伝導体を磁場中に置くとマ イスナ一効果により磁場は超伝導体から排除されるが下部臨 界磁場を越える磁場中に置くと磁束は渦糸状態で磁束線とし て超伝導体内に浸入する. 超伝導材料は不純物や結晶粒界な どにより磁束線を留め, このことをピン止めと呼ぶ. ピンニ ング強さが弱いと上部臨界磁場が低くなり超伝導体材料とし て使用できる範囲が狭くなる. 超伝導体のピンニング強化と して酸素欠損の結晶構造での原子レベル欠陥, 重イオン照射 による柱状欠陥が有効であり ${ }^{21}$, カーボンナノチューブを混 入させた部分溶融焼結体で, 同様の効果を得る事ができ, Bi2212超伝導体においてピンニング作用が強化されたとの報 告がある ${ }^{3)}$.また Pbを高ドープした単結晶の報告もある4). 一 方, 炭素が超伝導体に対して否定的な影響を有していること が, Tenbring et al. ${ }^{5)}$, Seibt et al. ${ }^{6)}$, およびZhang et al. ${ }^{7)}$ によっ 
て Bi2212 およびBi2223 銀シーステープを用いた研究で報告 されている.

本研究では第2種超伝導体の類であるBi系銅酸化物超伝導 体を用い，固相法による多結晶Bi2223 超伝導体に対して， カーボンナノチューブ (Carbon-Nano-Tube: 以下CNTと略す) を混入し, 熱処理した試料において超伀導体内に空洞または 他の拡大された欠陷を形成することによりピンニング作用が 強化されるかをどうか調べた。

CNTを混入することによって, CNTの還元力により超伝導 体内の酸素が炭素と共に引き抜かれ, 高温相が低温相や極低 温相に分解し, 窒素気流中で十分な時間で熱処理することに より金属銅まで還元するという結果を得たので報告する．

\section{2 実験方法}

本研究では高温相の Bi2223 超伝導体を親試料として作製 し, 使用した. 原料粉は酸化ビスマス $\left(\mathrm{Bi}_{2} \mathrm{O}_{3}\right)$, 酸化鉛 $(\mathrm{PbO})$, 炭酸ストロンチウム $\left(\mathrm{SrO}_{3}\right)$, 炭酸カルシウム $\left(\mathrm{CaCO}_{3}\right)$ および 酸化銅 $(\mathrm{CuO})$ で, 純度は $99 \%$ 以上のものを使用した。上記の 原料粉を金属イオンモル比 $\mathrm{Bi}: \mathrm{Pb}: \mathrm{Sr}: \mathrm{Ca}: \mathrm{Cu}=1.85: 0.35: 1.9$ : 2:3.1で, 質量 $5 \mathrm{~g}$ になるように電子天秤を用いて秤量した. Bi2223単相のみを得るのは非常に困難であるため, 上記の通 り酸化鉛を入れることによりBi2223相を得やすくした. 秤量 した原料粉をメノウ乳鉢および遊量型微粒粉砕機(P-7フリッ チェ社製) ボールミルで粉砕混合した．ボールミルで粉砕混 合する際には容器にそれぞれの原料粉とアセトンとを原料粉 が浸る程度入れ，アルミナボール (約 $5 \mathrm{~mm} \phi)$ を 5 個で， 3 時 間混合した後, $100^{\circ} \mathrm{C}$ の乾燥機でアセトンを蒸発させた.

乾燥した原料粉末を 1 次焼成するために金製の器に移しア ルミナ製の土台と板を重ね, その上に粉末の入った金の器を 載せ，耐火レンガ上に置いた状態で電気炉の中に入れる。炉 内の温度制御はコンピュータのプログラムで制御し, $800^{\circ} \mathrm{C} て ゙$ 20 時間焼成し $100^{\circ} \mathrm{C}$ まで徐冷したのち室温で放冷した. 1 次 焼成後义ノウ乳鉢で粉砕し試料を $0.5 \mathrm{~g}$ ずつ秤量する.その後

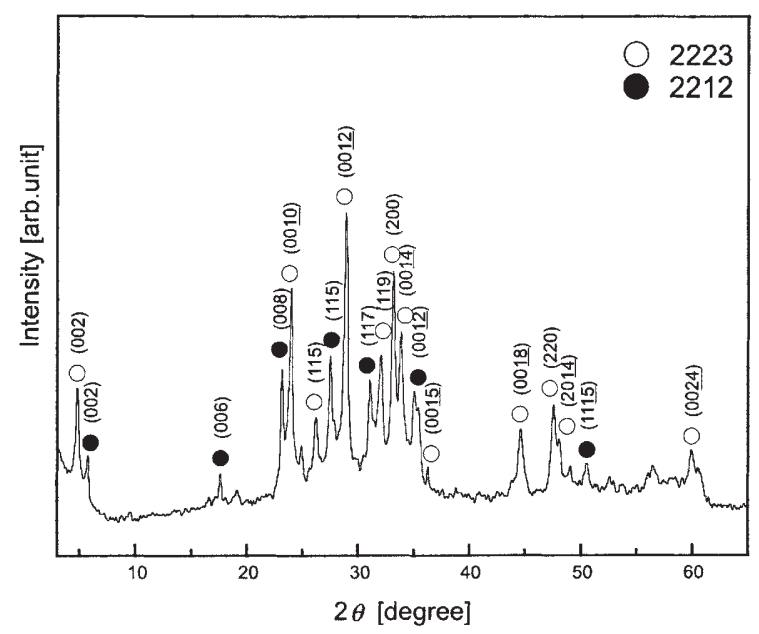

Fig.1 XRD pattern of Bi2223 sample.
粉砕試料を $12 \mathrm{~mm} \phi$ の金型でペレット状にし，プレス機を用 いて $30 \mathrm{MPa}$, 90 秒で 1 軸加圧成型した. 2次焼成のためにぺ レットを約 $15 \mathrm{~mm}$ 四方の金製の板に載せ, 耐火レンガに置 く.これを電気炉で最高温度 $850^{\circ} \mathrm{C}$ の状態で 120 時間焼成し た. その後 $500^{\circ} \mathrm{C}$ で炉から取り出し大気中で急冷させた.

このBi2223 超伝導体を親試料として, メノウ乳鉢で粉砕 し，親試料に対して0〜 $5 \mathrm{wt} \%$ の CNTをそれぞれ秤量した. 秤量後, それを親試料粉末があるメノウ乳鉢に移し, 再度粉 砕混合した. 混合粉末を $12 \mathrm{~mm} \phi$ 金型に入れ $40 \mathrm{MPa}$ で 90 秒 1 軸 加圧成型した.ペレット化した試料を約 $15 \mathrm{~mm}$ 四方の金製の 板に載せ耐火レンガに置き, これを管状炉で大気雾囲気, 窒 素雾囲気中でそれぞれ $800^{\circ} \mathrm{C}$ で 24 時間熱処理した.

CNTはHyperion Catalysis 社, 単繊維長 $=10 \mu \mathrm{m}$, 純度 $\geqq 90 \%$ のものを使用し, 試料の評価は, X 線回折測定によって結晶 相の同定および電気特性の測定として4端子法を使用した抵 抗率温度依存测定と臨界電流密度 $\mathrm{Jc}$ 测定を零磁場, $77 \mathrm{~K}$ およ び $65 \mathrm{~K}$ で測定を行なった。

\section{3 実験結果および考察}

初めに, 各条件で得られたCNT試料と比較・検討するため にBi2223親試料についてX線回折測定, 抵抗率温度依存測定, 臨界電流密度測定を行った. Fig.1にX線回折測定の結果を示 す. Bi2223 漞試料ではPbOを入れることにより高温相が安定 化されて入るが, Bi2223単相だけ得る事は非常に困難であっ た. 低温相と高温相の共存割合は $1: 2.5$ と高温相が多く, PbO を含むことによって $\mathrm{Ca}_{2} \mathrm{PbO}_{4}$ が検出される場合が多いがこの 試料では検出されなかった. 試料の $c$ 軸長は $\mathrm{C}=30.8 \mathrm{~nm}$ ( 低 温相) およびC $=36.9 \mathrm{~nm}$ (高温相) であった. Fig.2 は Bi2223 親試料の抵抗率温度依存測定の結果を示す. Bi2223親試料の

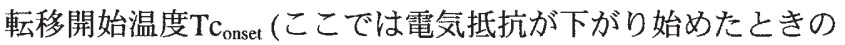
温度とする) が $104 \mathrm{~K}$, 転移終了温度 $\mathrm{Tc}_{\mathrm{offset}}$ (ここでは電気抵

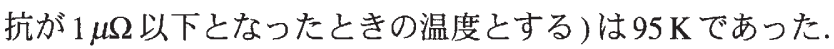
$273 \mathrm{~K}$ の抵抗率は $3 \mathrm{~m} \Omega \mathrm{cm}$ である. Fig. 3 では零磁場下・液体

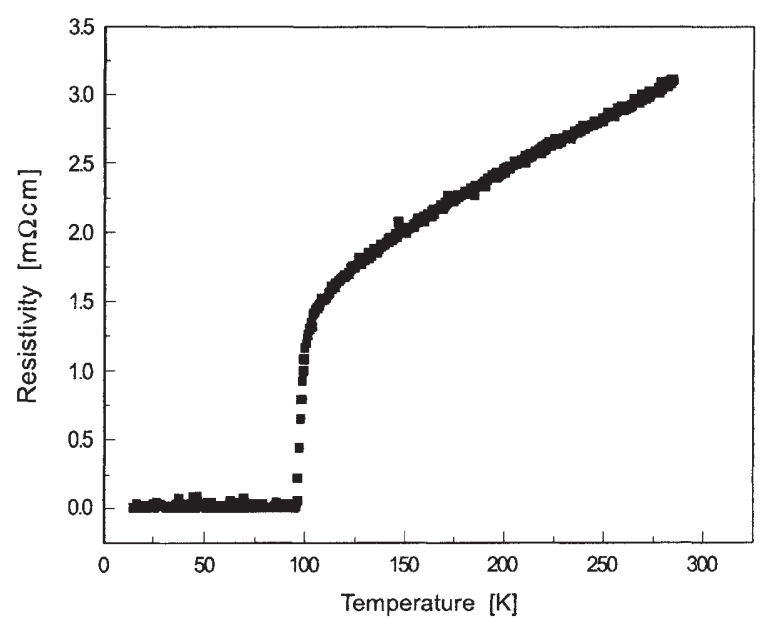

Fig.2 Temperature dependence of resistivity for Bi2223 sample. 
窒素温度 $77 \mathrm{~K}$ での臨界電流密度 $\mathrm{Jc}$ 测定を行った. 臨界電流以 上をを流すと電気抵抗が生じるので臨界磁場を越え超伝導体 ではなくなる。電流密度は $2 \mu \mathrm{V} / \mathrm{cm}$ の電界が生じたときの電 流密度を $\mathrm{Jc}$ として，ここでは $\mathrm{Jc}=23.5 \mathrm{~A} / \mathrm{cm}^{2}$ であった。

次に試料にCNTを加え大気霉囲気中で熱処理したものを Fig.4でX線回折, Fig.5で抵抗率温度依存測定の結果を示す. Fig.4では, Oが高温相，○が低温相であり，CNT0wt\% 混合 し24時間熱処理を施したものは, 低温相と高温相を比較した とき共存割合が $1: 1.85$ と高温相が多くを占めており, 親試料 と比較しても遜色ないことから熱処理のみによる影響はない といえる. CNT $0.1 \mathrm{wt} \%, 0.5 \mathrm{wt} \%, 1 \mathrm{wt} \%, 5 \mathrm{wt} \%$ と加えてい くことによってX線回折は，高温相が少なくなり変わりに低 温相が多くを占めてくる.特に29付近にある高温相の $(0012)$ 割合が徐々に減少し, 27 付近にある低温相の(115)が増加して

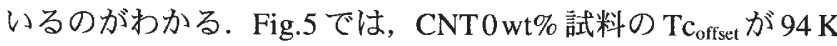
と親試料に近いが，それに対して CNTを加えていったもの

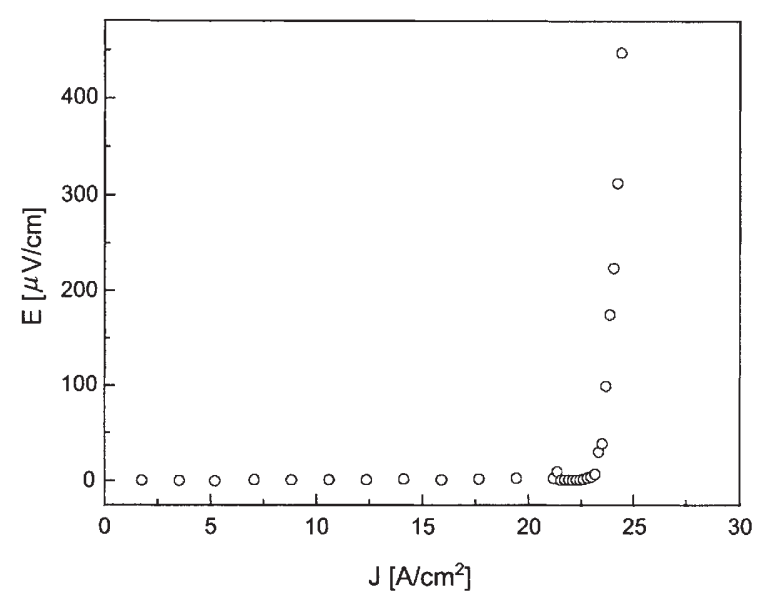

Fig.3 Electric field vs current density curve at $77 \mathrm{~K}$ for $\mathrm{Bi} 2223$ sample.

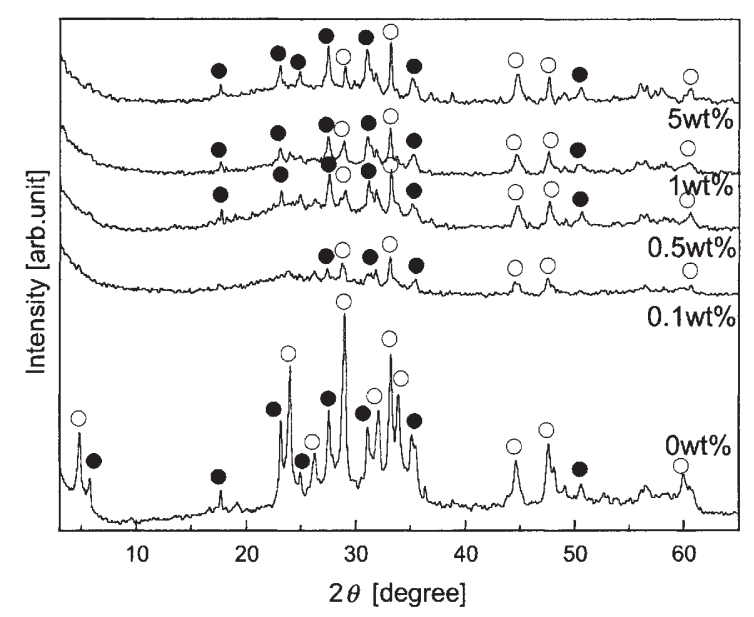

Fig.4 XRD patterns of CNT embedded samples heated in air atmosphere.Open circles are high Tc phase. Solid circles are low Tc phase.
は, CNT混合量を増やしていくことによって $\mathrm{Tc}_{\text {offset }}$ が隇少し ていく.これはX線回折から高温相が減少して低温相が増加 していることと一致している.

次に試料にCNTを加兑窒素雾囲気中で熱処理したものを Fig.6でX線回折, Fig.7で抵抗率温度依存測定の結果を示す. $\mathrm{X}$ 線回折測定から, CNT $0 \mathrm{wt} \%$ 試料が窒素雾囲気中で熱処理 することによって, CNTの有無にかかわらず高温相が破壊さ れ大半を低温相が占めるようになり更には極低温相までもが 見られるようになった. CNT混合量を增やしていくことで低 温相は少なくなり極低温相が多くを占めるようになる.それ は $0 \mathrm{wt} \%, 0.5 \mathrm{wt} \%$ の $27^{\circ}$ 付近の低温相で確認できたものが, $1 \mathrm{wt} \%, 5 \mathrm{wt} \%$ では確認できなくなり，29\%付近にある極低温 相が大きく出てくることからもわかる. 抵抗率温度依存測定 では, CNT0wt\% で Tc $\mathrm{offset}_{\text {が }} 69 \mathrm{~K}$ と CNT 混合していなくて も, 窒素雾囲気中で熱処理を行っただけで $\mathrm{Tc}_{\mathrm{ofssel}}$ は低下した.

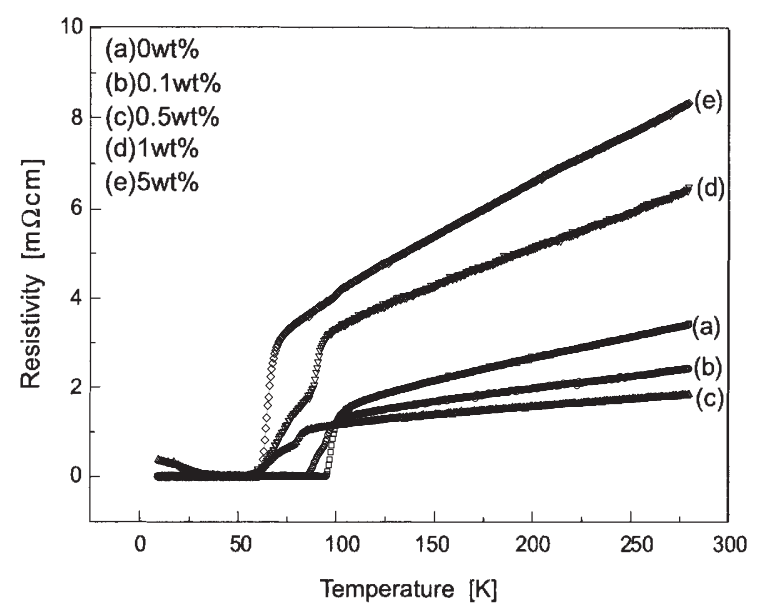

Fig.5 Resistivity vs temperature curves of CNT embedded samples heated in air atmosphere.

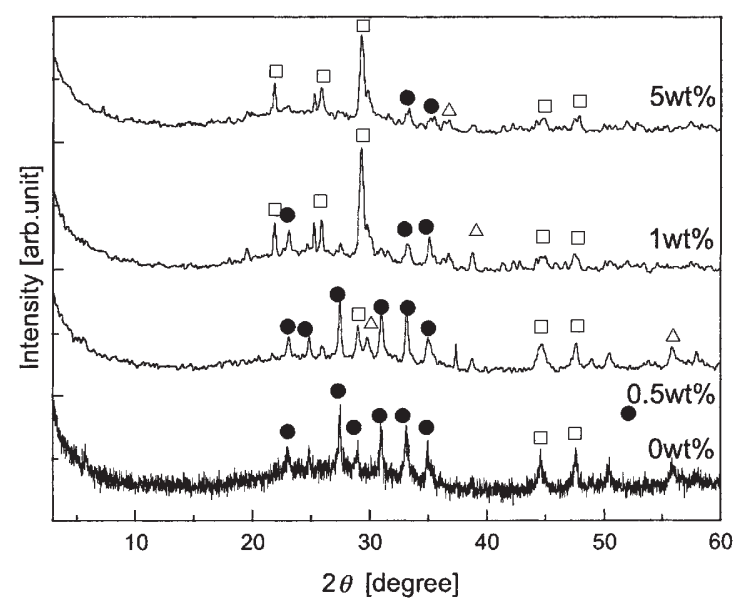

Fig.6 XRD patterns of CNT embedded samples heated in $\mathrm{N}_{2}$ atmosphere. Solid circles are low Tc phase. Open squares are very low Tc phase. Open triangles are $\mathrm{CuO}$. 


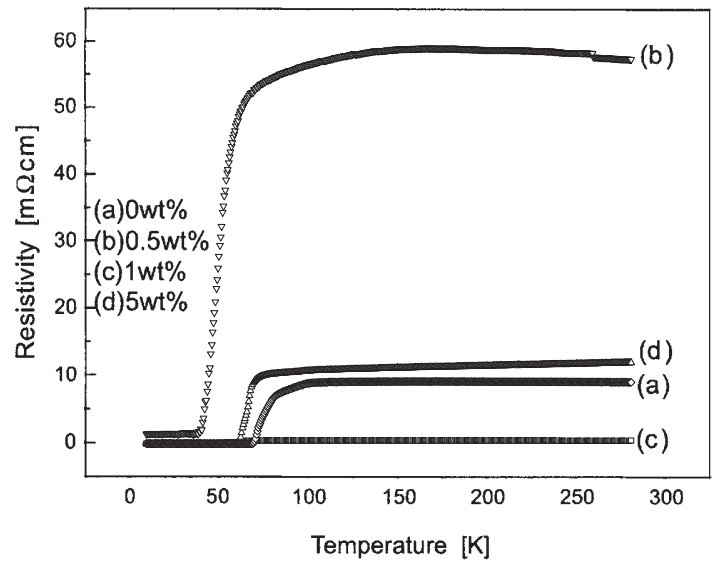

Fig.7 Resistivity vs temperature curves of CNT embedded samples heated in $\mathrm{N}_{2}$ atmosphere.

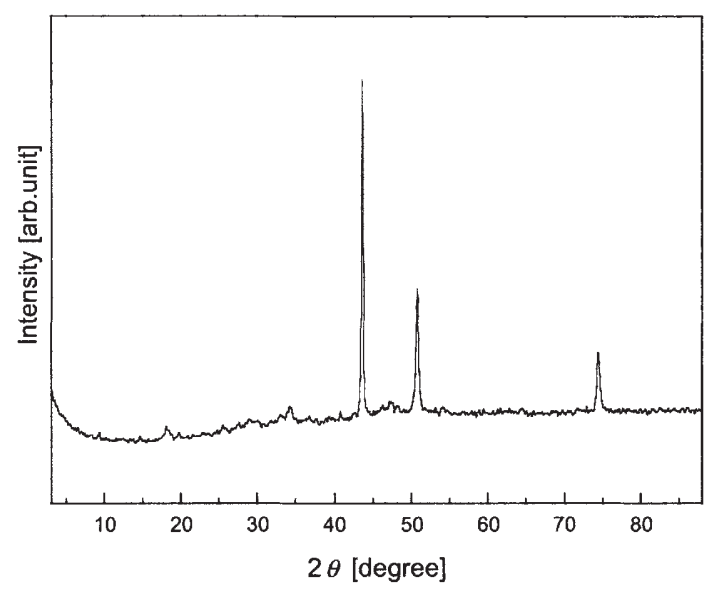

Fig.8 XRD pattern of sample at $\mathrm{N}_{2}$ atmoshere.

CNT 混合量を増加させることによって, 0 wt \% の $\mathrm{Tc}_{\text {offset }}$ より も低下している.このことはX線回折から, 低温相が減少し, 極低温相が増加することと一致している. 窒素雾囲気中で超 伝導体の質が落ちる理由として, 大気中の酸素と反応できな いために, CNTは超伝導体内で反応し, 超伝導体構造が破壊 されるためだと予測される。

CNTを混合し窒素雾囲気中で熱処理することで, X線回折 測定や抵抗率温度依存測定の結果が悪くなるのは次のことか らもいえる. Fig.8で示すX線のピークは試料にCNTを $5 \mathrm{wt} \%$ 混合して窒素雾囲気中で熱処理した時に得られたX線回折測 定の結果である.もともとBi2223超伝導体であったものが別 のものに変化しているのがわかる.このピークを調べたとこ ろ金属銅のピークと一致した.このことからCNTを混合し窒 素雾囲気中で熱処理をおこなうと, CNTが強い還元剤の役割 をしてBi2223超伝導体中の銅を金属銅にまで還元してしまう 場合があることがわかった．同じCNTを $5 \mathrm{wt} \%$ 混合し，窒素 雾囲気中で熱処理をおこなったものが一方では金属銅まで還 元したのは, 窒素の流量が原因である. 窒素の流量が多かっ

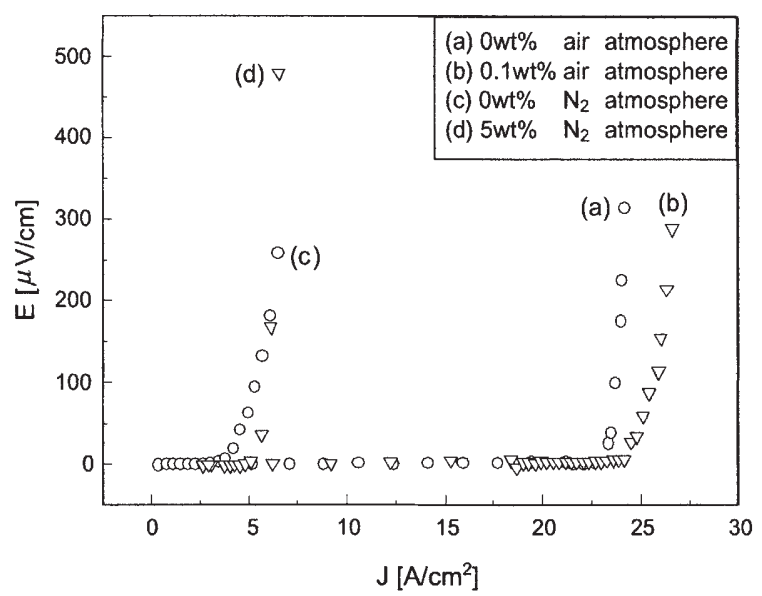

Fig.9 Electric field vs current density curves at $77 \mathrm{~K}$ and $65 \mathrm{~K}$ of air and $\mathrm{N}_{2}$ atmosphere samples.

たために, 試料中の銅の多くが還元し, 同じ条件であっても 窒素の流量によって違いが生じた.

最後に臨界電流密度測定の結果を Fig.9 に示す. CNTを混 合したことによって超伝導体が破壊され, 臨界電流密度测定 の測定温度以上で超伝導体にならないものもあったため測定 できたものだけを比較した. 大気雾囲気中と窒素雾囲気中と では, 大気雾囲気中の臨界電流密度のほうが高い值を示した。 また大気雾囲気中と窒素雾囲気中の両方で, CNTを混合した (b) と (d)の方が臨界電流密度が混合していない (a) と (c)に比 ベ上昇している.このことからCNTを混合することによって ピンニング作用の強化がおこり, 超伝導体の磁束密度が上昇 する. しかしながら, CNTを混合したことによって超伝導体 が破壊され, 臨界温度は低下しており, 測定できないものも あったことから, ピンニング作用の強化はおこるが超伝導体 材料としては質の悪いものになる.

CNTは超伝導体試料と混合する際に, 超音波などを用いて 超伝導体試料全体にCNT を分散させる必要がある。CNTは 超伝導試料に混合し熱処理するときに酸素と反応させること で, CNTを少量消費して試料中に空洞や拡大された欠陥を形 成させるが,このときCNTの分散が不十分な場合, 試料中の 一部に空洞や欠陥が偏るため, 超伝導体の破壊を引き起こす 原因となつたと考えられる ${ }^{31}$.

\section{4 結言}

$\mathrm{Bi}$ 系銅酸化物超伝導体 Bi2223にCNT を埋め込むことに よって, 超伝導体の臨界電流密度が上昇するという報告を受 け研究を行った. 大気雾囲気中でCNTを埋め込むとこによっ て超伝導体内中の銅と反応し, 臨海温度 Tcが低下するが, 臨 界電流密度Jcは埋め込んだことによってピンニングが強化さ れ上昇する.しかし臨界温度 Tcは低下し, 臨界電流密度 $\mathrm{Jc}$ を 測定できないものもあり, 超伝導体としては質のよいもので はない. 窒素雾囲気中では, CNTを埋め込んだことによって 
Bi 超伝導体中の酸素と反応し酸化銅が金属銅にまで還元さ れ，Bi2223相が著しく破壊され高い臨界温度を維持できなく なるほどであった.このことから大気雾囲気中および窒素雾 囲気中でCNTを埋め込むことでピンニングは強化され超伝導 体の臨界電流密度が上昇するが，その一方，CNTを埋め込む と，超伝導中の銅を金属銅にまで還元させてしまうという大 変強い還元剤として作用することを示した.

\section{文献}

1) For example ed. by M.Tachiki and T.Hujita: SCIENCE OF HIGH TEMPERATURE SUPERCONDUCTIVITY, SHOKABO, (1999).

2) W.Gerhauser et al.: "Flux-Line Pinning in $\mathrm{Bi}_{2} \mathrm{Sr}_{2} \mathrm{Ca}_{1} \mathrm{Cu}_{2} \mathrm{O}_{X}$ Crystals: Interplay of Intrinsic 2D Behavior and IrradiationInduced Columnar Defects", Phys. Rev. Lett., 68(6)(1992)879882
3) Sun-Li Huang et al.: "Microstructure and flux distribution in both pure and carbon-nanotube-embedded $\mathrm{Bi}_{2} \mathrm{Sr}_{2} \mathrm{CaCu}_{2} \mathrm{O}_{8+\delta}$ superconductors", Physica C, 311(1999) 172-186.

4) I.Chong et al.: "High critical-Current Density in the Heavily $\mathrm{Pb}$ -Doped $\mathrm{Bi}_{2} \mathrm{Sr}_{2} \mathrm{CaCu}_{2} \mathrm{O}_{8-\mathrm{X}}$ Superconductor: Generation of Efficient Pinning Centers", Science, 276(1997)770-773.

5) J.Tenbring et al.: "DEVELOPMENT OF High-Tc SUPERCONDUCTOR WIRES FOR MAGNET APPLICATIONS", IEEE TRANSACTION ON MAGNETIC, 27(2)(1991)1239-1246.

6) E.W.Seibt: "Effects of carbon impurities in high Tc superconducting tapes using Auger electron spectroscopy", Thin Solid Films, 228(1993)196-200.

7) W.Zhang et al.: "The influence of carbon on melt processing Ag sheathed $\mathrm{Bi}_{2} \mathrm{Sr}_{2} \mathrm{CaCu}_{2} \mathrm{O}_{8}$ tape", Physica C, 234(1994)137145 . 